\title{
Global challenges facing plant pathology: multidisciplinary approaches to meet the food security and environmental challenges in the mid-twenty-first century
}

Michael Jeger ${ }^{*} \mathbb{0}$, Robert Beresford ${ }^{2}$, Clive Bock $^{3}$, Nathan Brown $^{4}$, Adrian Fox $^{5}$, Adrian Newton ${ }^{6}$, Antonio Vicent ${ }^{7}$, Xiangming $\mathrm{Xu}^{8}$ and Jonathan Yuen ${ }^{9}$

\begin{abstract}
The discipline of plant pathology has an expanding remit requiring a multi-faceted, interdisciplinary approach to capture the complexity of interactions for any given disease, disease complex or syndrome. This review discussed recent developments in plant pathology research and identifies some key issues that, we anticipate, must be faced to meet the food security and environmental challenges that will arise over coming decades. In meeting these issues, the challenge in turn is for the plant pathology community to respond by contributing to a wider forum for multidisciplinary research, recognising that impact will depend not just on advances in the plant pathology discipline alone, but on interactions more broadly with other agricultural and ecological sciences, and with the needs of national and global policies and regulation. A challenge more readily met once plant pathologists again gather physically at international meetings and return to the professional and social encounters that are fertile grounds for developing new ideas and forging collaborative approaches both within plant pathology and with other disciplines. In this review we emphasise, in particular: the multidisciplinary links between plant pathology and other disciplines; disease management, including precision agriculture, plant growth and development, and decision analysis and disease risk; the development and use of new and novel plant protection chemicals; new ways of exploiting host genetic diversity including host resistance deployment; a new perspective on biological control and microbial interactions; advances in surveillance and detection technologies; invasion of exotic and re-emerging plant pathogens; and the consequences of climate change affecting all aspects of agriculture, the environment, and their interactions. We draw conclusions in each of these areas, but in reaching forward over the next few decades, these inevitably lead to further research questions rather than solutions to the challenges we anticipate.
\end{abstract}

Keywords: Plant pathology and multidisciplinary approaches, Disease management, Genetic diversity, Plant microbiome, Exotic plant pathogens and plant health, Climate change impacts

\section{Background}

Plant pathology is the scientific study of plant diseases and pathogenic agents ${ }^{1}$ across a diverse range

*Correspondence: m.jeger@imperial.ac.uk

${ }^{1}$ Imperial College London, London, UK

Full list of author information is available at the end of the article of environments including agricultural and horticultural crops, amenity and forest trees, and natural plant

\footnotetext{
${ }^{1}$ For the purposes of this review, we consider pathogenic agents to include fungi, oomycetes, bacteria and phytoplasmas, viruses and viroids, and macroparasites including parasitic plants and nematodes. We note that the pathogenic phase may only form part of their life history.
}

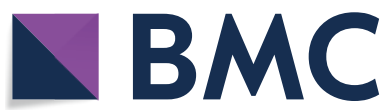

(c) The Author(s) 2021. This article is licensed under a Creative Commons Attribution 4.0 International License, which permits use, sharing, adaptation, distribution and reproduction in any medium or format, as long as you give appropriate credit to the original author(s) and the source, provide a link to the Creative Commons licence, and indicate if changes were made. The images or other third party material in this article are included in the article's Creative Commons licence, unless indicated otherwise in a credit line to the material. If material is not included in the article's Creative Commons licence and your intended use is not permitted by statutory regulation or exceeds the permitted use, you will need to obtain permission directly from the copyright holder. To view a copy of this licence, visit http://creativeco mmons.org/licenses/by/4.0/. The Creative Commons Public Domain Dedication waiver (http://creativecommons.org/publicdomain/ zero/1.0/) applies to the data made available in this article, unless otherwise stated in a credit line to the data. 
communities. The broad range of pathogens and affected hosts can lead to specialisation within the science and has the potential to constrain a shared approach and dialogue among plant pathologists, especially with respect to disease management. There are examples where a shared approach has been shown necessary and productive, such as with soil-borne diseases with interactions among multiple agents, e.g., fungi and nematodes (Zhang et al. 2020); or, where the involvement of vectors in the transmission and spread of viruses, bacteria and fungi is seen as a common feature that can be exploited in disease management. However, much published research is dominated by the single pathogen, single crop, single disease paradigm. Within plant pathology, a paradigm shift may be required to view pathogens and diseases as components of ecosystems, including farming systems, and to describe their epidemiology and management more quantitatively. Current concepts in plant pathology which have provided much of our understanding of when and how diseases develop, need to be re-visited and integrated into a wider quantitative framework that can be applied across disciplines. Basic tenets of plant pathology, such as the 'disease triangle' (Agrios 2005), the 'disease life cycle' (De Wolf and Isard 2007) and Koch's postulates (Agrios 2005) need to be examined, and possibly modified or replaced with concepts more suited to integration with crop agronomy and ecosystem functions and services in the search for more robust disease management strategies and applications.

A problem in plant pathology, perversely, is the term 'pathogen. The pathogenic phase of a microbial parasite is only one aspect of a plant-microbe interaction that should always be qualified by spatial and temporal parameters. So, plant pathology should be the study of all the factors that influence the interactions between plants and microbes and their outcomes both spatial and temporal, and how these can be managed towards a benign or beneficial state, as with rhizobia. This would mean widening the approach to genetic diversity to bring in susceptibility as well as resistance determinants and would re-visit non-host resistance as well: the 'trophic space' of the plant-microbe interaction (Newton et al. 2010a, b). The discussion above focusses on disease, i.e., the symptomatic expression of microbial infection. However, under-represented in our evaluation of the effects of microbes is asymptomatic infection. Such infection or colonization can have a range of effects from unrecognized source of inoculum, through induction of defence responses that may have short-term cost through to longterm benefits (Atkins et al. 2010; Newton et al. 2010a, b). Asymptomatic microbes can also be endophytes conferring benefits on their hosts such as resistance to herbivores exploited in highly beneficial ways in grass cultivars developed in New Zealand for example, or to induce effective resistance against fungal pathogens in cereals as well as promoting crop growth (Gill et al. 2016). However, the challenge is how to bring together the detailed molecular and the whole crop systems in practice. This can only be achieved by a multi-disciplinary approach.

There are also multidisciplinary ${ }^{2}$ links and interactions with other plant protection disciplines, plant breeding, crop management, food safety and security, phytosanitary regulation, soil science, and plant and environmental health more generally, although these links have often been implicit rather than explicit in research endeavours. All these interactions fall within the broad term of systems biology where understanding the interactions among components is crucial. Over the next decades, global issues relating to climate change and international biosecurity associated with increasing trade and air travel will lead to new challenges in all areas of agriculture and the environment, including the management of plant diseases and their societal impact. Hence, a forum for communication of research findings related to these global issues, from the molecular and ecological interactions among plants, pathogens, other microbiota, and vectors, to aetiology and epidemiology of disease in field populations and diverse landscapes, is essential if these challenges are to be met. We recognise of course that there are many challenges purely within the 'traditional' plant pathology domain, and acknowledge their importance, but these can be considered and presented elsewhere. Accordingly, this review is structured according to key topics (Fig. 1) where the scope for taking a multidisciplinary approach to global issues is most apparent. For each topic we outline the challenges and opportunities that will arise over the next decades, and in some cases propose solutions.

\section{The interface between plant pathology, crop protection and other disciplines in agricultural and environmental sciences}

Plant pathology shares an interface with all disciplines in agricultural and environmental sciences. This interface is fundamental in meeting the challenges of food security and environmental stewardship in the twenty-first century (Fig. 2). In crop protection, there is an increasing need for pathologists and entomologists to work together in an integrated approach to pest management (Jactel et al. 2020). Approaches to pest ${ }^{3}$ risk analysis in

\footnotetext{
${ }^{2}$ For this term, we include interaction across disciplines and at the interface between disciplines.

3 'Pest' can refer collectively to 'pathogens', 'invertebrates', and 'weeds' in the international biosecurity context, whereas within the individual disciplines of plant pathology, entomology and weed science, the respective individual terms are more often used and pest tends to be reserved for invertebrate pests.
} 


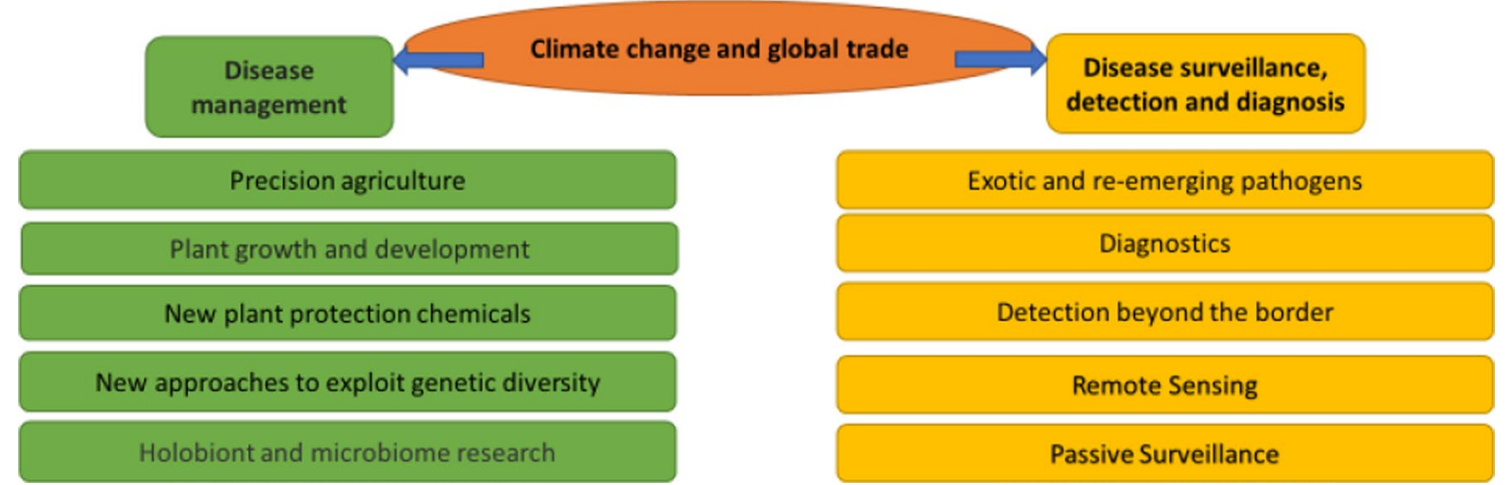

Fig. 1 Schematic showing topics within plant pathology where multidisciplinary approaches in research have been developed but need further implementation as described in this review. The two arms of the schematics are shown for ease of presentation. Cross links between the two are present and for some there has been wider involvement of farmers, landholders, regulators, and other participants, but in all areas there will be a need for improvement to meet future challenges as discussed in this review

plant health are already benefitting from integration across disciplines; especially concerning formal phytosanitary systems as specified under the International Plant Protection Convention (IPPC), or more informal seed certification schemes in support of sustainable crop production. Agronomic practices of irrigation, soil management and sanitation have long been known to be key components in plant disease management strategies for agricultural and horticultural crops (Jeger 2005). Canopy and soil moisture management, tillage, soil amendments, sowing seasons, and crops sequences, are major cultural practices in crop protection resulting in disease escape, inoculum reduction and microclimate modification, but are often considered as single practices rather than an integrated whole. Agronomic practices often change due to a range of social and environmental factors. Shortage of labour has led to a change in rice cultivation from transplanting to direct seeding (Savary et al. 2005). When direct seeding was combined with poor management due to water shortages, the pest profiles changed due to direct effects and interactions between the two factors, with some pest impacts increased and others decreased. This analysis was further expanded to include fertilizer treatment and availability of land as factors of agronomic change, with again both positive and negative impacts on the pest profile (Savary et al. 2011). The concept of a pest profile was subsequently expanded to that of a crop profile including many agronomic components as well as the pest profile and impacts (Savary et al. 2017). At the interface with social sciences, cultural practices for disease control often require shared responsibility and need a collective approach to disease management among growers to be implemented at a regional level.

There is a wide range globally of farming systems that vary according to climate, topography, and geo-political and socio-economic factors. A distinction has often been made between low-input and intensive farming systems but perhaps there has been insufficient critical examination of this distinction and there may be disease management solutions that apply to both. Non-chemical interventions for disease control are of increasing importance in the context of low-input agricultural systems, where the use of fungicides and insecticides is limited, but there are also incentives for reduced chemical interventions in intensive systems. Non-chemical methods are paramount for disease control in organic farming systems, but the fungicides allowed are often less effective than their synthetic alternatives (Tamm and Holb 2015). Strategies for use of non-chemical methods are more complex to implement and a greater research effort into these is required. Low-input agricultural systems apply both in less-developed countries, where external resources and farm inputs are not always readily available, and in developed countries, where more sustainable crop production is driven by consumer preferences and environmental policies, rather than the lack of resources. The demand for access to synthetic pesticides and fertilizers can be expected to continue in the short-term until more durable management methods are found to be effective. 


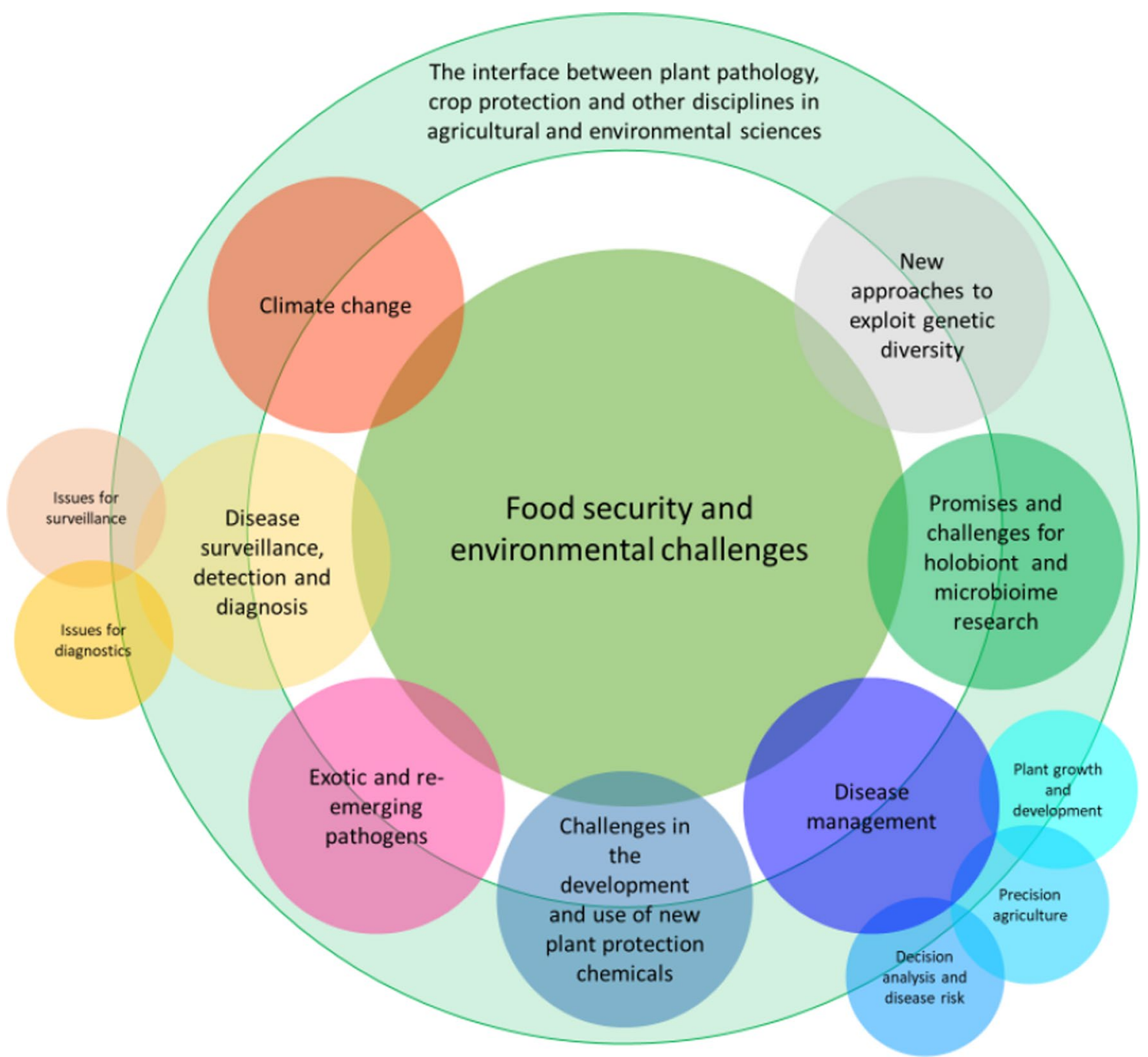

Fig. 2 Venn diagram representing the multidisciplinary challenges faced as plant pathology addresses burgeoning issues of food security and environmental stewardship in the twenty-first century. The ring represents the first challenge: the interface between plant pathology, crop protection and other disciplines. Each of the surrounding seven circles represents one of the remaining major challenge areas identified and discussed in the article. All seven of challenges channel results of research into food security and environmental stewardship. The seven challenge areas are themselves interconnected. Sections "Disease surveillance, detection and diagnosis" and "Disease management" have additional, specific areas of challenge discussed herein and indicated by the accompanying smallest circles in this figure

It is possible that information-based intensification of crop production may contribute to a greater sustainability and more effective use of resources. Such intensification is equally applicable irrespective of the level of external inputs to the system, although new approaches will be needed to ensure information is accessible to resourcepoor farmers in less developed countries and regions. Examples of intensification can be found in what has been termed precision agriculture, a greater appreciation of the role of plant growth and development in disease epidemiology, and greater contribution to the theory and practice of Integrated Pest Management (IPM), ultimately leading to a recognition that Integrated Crop Management (ICM) should be the goal. In practice, IPM is a term often used by practitioners in crop protection when it should be ICM.

The interfaces among the topics considered in this review (Fig. 1) and the ways in which they contribute to food security and environmental challenges of the twenty-first century are shown in a Venn diagram (Fig. 2).

\section{Disease management}

The purpose of disease management is to maintain and improve plant health and production, whether in cropped, semi-natural, or non-cropped systems. 
Pathogens and pests reduce yield, both quantitatively and qualitatively, in crop production causing economic losses and threatening food security. Yield reductions have been documented for five globally important crops, wheat, rice, maize, potato, and soybean (Savary et al. 2019), in the order of $10-40 \%$ with most impact reported in resource-poor regions with fast-growing populations. Future projections of such analysis can serve to prioritize crop health management in the coming decades, both regionally and globally. The impacts of plant disease on ecosystem services in both cropped and non-cropped systems needs to be considered in any yield loss inventory (Cheatham et al. 2009; Avelino et al. 2018).

The historical reliance on highly effective fungicides for disease control, and, to some extent, insecticides for virus vector control, has shaped the way plant pathologists think about plant diseases and their management. It has not always been the case that innovations and developments in disease control have depended on advances in epidemiological understanding (Jeger 2004). In the future, as microbial biocontrol agents, plant defense elicitors and possible microbiome manipulations become available, and reduce the reliance on synthetic pesticides, a new understanding of the role of plant pathogens and the diseases they cause in whole cropping systems and in the provision of ecosystem services will be needed. This will require greater integration of plant pathology concepts and methodologies with those of other disciplines so that the processes driving disease epidemics and our ability to deliver new disease management systems can be conceived in a wider context.

For plant diseases, resistance is widely recognized in the context of plant breeding and molecular host-pathogen interaction as referring to resistance genes or quantitative traits, but less in terms of how resistant cultivars should be deployed in cropping systems. In terms of crop management, the term 'vulnerability' conveys better the varying impact that environmental, agronomic and host phenology factors have on disease in host plant populations. Comparing host plant resistance in terms of symptom expression in a mature conservation agriculture context between inversion and non-inversion tillage, the difference can be an order of magnitude. However, the underlying factors can be multiple, including inoculum (quality and quantity), microbial/microbiome interactions, microclimatic, and nutrients (both micro- and macro-). Diversity in the system at all levels is clearly a major component of vulnerability in practice, but how can this be quantified in determining how all the components of diversity interact? The relevant literature is mostly based on ecological principles, but specific aspects of exploiting host diversity such as the use of cultivar mixtures in space and time to reduce fungicide input and mitigate fungicide resistance development represents a practical implementation in ICM (Kristoffersen et al. 2020).

\section{Precision agriculture}

Precision agriculture presents opportunities for all farming systems. The advent of precision farming technologies coupled with remote sensing methods opens entire new fields of research, where the performance of cultural practices for plant disease management can be addressed (Kitchen 2008). With the aid of artificial intelligence and machine learning algorithms, these technologies may allow an integration of the spatiotemporal dynamics of disease at the farm level with environmental data, soil characteristics and agronomic practices, leading to more targeted disease control interventions. Precision agriculture (including horticulture) has the potential to deliver the transformation of farm productivity needed to meet future global food security and climate change challenges through information-intensive monitoring technologies and crop models that can predict productivity and the analysis of farming system performance. To achieve this for whole farming systems, it will be crucial to incorporate disease, pest and weed constraints into current process-based plant growth models such as the Agricultural Production Systems Simulator (APSIM; Keating et al. 2003). Research outputs in precision agriculture and plant pathology are still largely confined to disciplinebased core journals, so their interactions need a greater level of exploration and exploitation.

\section{Plant growth and development}

Despite the major advances in understanding the molecular underpinning of plant-pathogen interactions, there has been very little work on whole plant physiology, growth and development affecting disease in crop populations. The sensitivity of the cropping system to pathogen challenge needs to be tested during all stages of crop growth and phenology, so that their roles in crop loss and inoculum production can be more clearly understood. Disease susceptibility of different plant organs often varies during plant development, even in hosts considered genetically susceptible to a pathogen, e.g., for apple canker (Neonectria ditissima), stems and fruit become infected (Xu and Robinson 2010) but leaves do not. An organ's susceptibility may change during development as is seen in fungal fruit rots that express symptoms during fruit ripening, e.g., Colletotrichum spp. in apple (Grammen et al. 2019), Botrytis cinerea in tomato (Blanco-Ulate et al. 2016) and in grape (Mundy and Beresford 2007). Pea stipules under attack by Mycosphaerella pinodes (Didymella pinodes) increase in susceptibility as they age (Richard et al. 2012). Our perception of host susceptibility 
is understandably oriented towards the plant organ on which economic production depends. Disease may affect the organ of interest directly, e.g., leaf area destruction in essential oil crops, or indirectly, e.g., the depression of grain yield caused by destruction of photosynthetic leaf area in cereal foliar pathogens. However, disease on other organs may contribute inoculum to an epidemic, e.g., leaf spots caused by Pseudomonas syringae pv. actinidae contribute to kiwifruit bacterial canker (Froud et al. 2015), and, for apple scab, leaf lesions of Venturia inaequalis contribute both conidial and ascosporic inoculum to infections that render fruit unmarketable (Bowen et al. 2011). It is noteworthy that much of this research has been focused on individual pathogen/disease combinations with little consideration to how the consortium of pathogens changes during plant growth and development and impacts productivity.

The crop leaf canopy is crucial for both plant growth and disease development. Process-based growth models, including APSIM, generate virtual leaf canopies that simulate production and partition carbohydrates. This provides an opportunity to incorporate disease (and pest) processes as stressors inhibiting photosynthate accumulation. For many diseases, the leaf canopy is not uniformly susceptible to infection throughout its seasonal development and ontogenic resistance (Develey-Rivière and Galiana 2007) to biotrophic or hemi-biotrophic pathogens occurs in many host species. This change from susceptibility in young leaves to resistance in mature leaves occurs in many important diseases, including $V$. inaequalis on apple (Li and $\mathrm{Xu} 2008$ ) and in several powdery mildews, including Uncinula necator (Erysiphe necator) on grapevine (Ficke et al. 2003) and Podosphaera aphanis on strawberry (Asalf et al. 2014). Because ontogenic resistance restricts infection to actively growing shoots or in some cases to senescing plant organs, host growth determines the timing of seasonal epidemics. In many temperate crops, the season's leaf canopy is established during spring, which makes this an important time for the onset of disease epidemics. Only a few studies of epidemic dynamics mediated by host growth have been made, e.g., for apple scab (Beresford et al. 2004) and myrtle rust, caused by Austropuccinia psidii (Tessmann et al. 2001; Beresford et al. 2020). The architecture of the crop canopy is an important consideration, not only for issues relating to the microclimate and disease susceptibility, but in designing new crop varieties with desirable agronomic and crop protection traits (Costes et al. 2013).

\section{Decision analysis and disease risk}

One pest management issue needing more attention is related in part to the risk attitudes of decision makers and how this is related to how well predictive systems work or don't work. Although a theoretical approach based on Bayesian analysis has been developed for incorporating risk attitudes into evidence-based decision systems (Yuen and Hughes 2002; Nayak et al. 2018), there have been few empirical studies. What do farmers and decision makers want in a predictive system? The sensitivity (the proportion of positive predictions that are correct) and specificity (the proportion negative predictions that are correct) of the predictions made by different decision systems may be a critical issue, especially if the target groups (which could also vary) basically want a perfect sensitivity of $100 \%$. This contrasts with attitudes to weather forecasts where target groups would generally accept the prediction, even when it is qualified by a certain probability bound. Why should one demand more of one prediction, compared to another, especially when weather forecasts may play an important role in disease prediction? A framework has been proposed which combines risk perception, the subjective probability of disease occurrence and the impact of incorrect decisions may explain the failure in adoption of predictive schemes (McRoberts et al. 2011). Ultimately it is likely to remain the case over the next decades that decisions on plant disease risk and management will be based on incomplete data and analyses that are subject to high levels of uncertainty (McRoberts et al. 2019).

This is partly connected to risk attitudes that plant pathologists don't always consider and could benefit from the insights and expertise of both socio-economists (Sauter et al. 2015) and social psychologists (Mankad 2016). The interface between the plant diseases and their control, and why farmers (or growers, or advisors) make certain decisions is an issue that should be examined more thoroughly (Gent et al. 2013), with the input of social scientists. Indeed, it has been argued that purely technical assessments of disease risk may not provide an adequate understanding of the decisions made by growers and landowners, and those in the policy domain. Hence, more account needs to be taken of intuitive and normative social responses of individuals and organizations with possibly conflicting interests in managing plant disease (Mills et al. 2011; Ilbery et al. 2012). Equally the development of future public institutions concerned with plant health should be aligned with the needs, values and preferences of the communities affected by plant disease (Garcia-Figuera et al. 2021).

\section{Challenges in the development and use of new plant protection chemicals}

The application of conventional plant protection chemicals remains the dominant control method for many plant diseases worldwide, especially for fungal diseases. There is a need for research to assess the threat to sufficiency 
of global food production that may result from the widespread withdrawal of crop protection chemicals as active ingredients are banned worldwide for human health and environmental reasons. The tradeoffs between yield losses and potential environmental and health impacts of chemical disease control agents will require more attention, and not solely by plant pathologists, but also by related disciplines, crop producers and policy makers. This should be combined with analysis of the social factors associated with the adoption of new pest and disease management methods (Milne et al. 2015). In the last several decades many plant disease control chemicals have been banned or are now highly regulated for very limited use, an example being methyl bromide (Schneider et al. 2003). More recently there has been concern over the indirect effects of neonicotinoid pesticides applied as seed treatments on non-target organisms, including beneficial insects and bees. This has led to temporary bans on their use in some countries. Compared to field applied pesticides, there was much less knowledge among farmers about what active ingredients were being applied as seed treatments across a wide range of arable crops (Hitaj et al. 2020).

The cost of developing new products is high, and the regulatory hurdles continue to be stringent. But there are other practical issues that arise among both existing and novel disease control products, including loss of efficacy due to the pathogen developing resistance to the chemistry. Indeed, fungicide resistance is a recurrent issue in the management of numerous plant diseases (Brent and Holloman 2007; Stevenson et al. 2019), with more recently resistance developing to multiple modes of action in the same pathogen (Weber 2011). Thus, fungicide resistance and the need to manage existing chemistries becomes complex and challenging (Brent and Holloman 2007). Regulation, leading to a loss of many of the old, often broad-spectrum chemistries, and the cost of developing new products that are most often single site modes of action, is a harbinger that the impact of loss of fungicide sensitivity will likely increase. But can novel approaches be developed to reduce resistance breakdown in singlesite mode of action pesticides?

Thus, a challenge continues to be prolonging and maximizing the effective life of fungicides through an understanding of resistance fitness penalties (Hawkins and Fraaije 2018), advances in management approaches and tools, and in modeling various characteristics of resistance to better enable its management (Bosch et al. 2014). Here again we can be informed by a better understanding of the application of ecology to managing fungicides as recently demonstrated by the effect conferred by the heterogeneity of cultivar mixtures to mitigate against selection for fungicide resistance, specifically Septoria leaf blotch resistance in wheat (Kristoffersen et al. 2020), but the principles of exploiting diversity for resilience are likely to apply more widely.

A further major challenge is to develop effective new chemistries that have minimal impact on the environment and health yet have durable efficacy due to a low risk of resistance development (Hollomon 2015). Perhaps based on advances at the intersection of chemistry, biochemistry, molecular biology and genomics, 'designer' fungicides may be developed that address some of these issues, but again how best to deploy any new products will require evaluation during their development not as an afterthought. In the absence of appropriate plant genetic resistance, an ongoing challenge for the plant pathology community will be to continue to develop knowledge of pesticide resistance in populations of plant pathogens, understand mechanisms of that resistance as early as possible, and applying this knowledge to develop pesticide management programs that maximize efficacy while minimizing the risk of resistance developing. Another area of crop protection that has critical trade-off issues is the development and exploitation of resistance elicitors. Such products are generally not toxic but prime or activate plant defences thereby enhancing resistance. They are often not as efficacious as conventional biocidal crop protectants but in the era of ICM these are beginning to find their niche and we need to better understand how they can be developed as an asset to sustainable crop protection (Walters et al. 2014). Although the use of these resistance elicitors or more generally priming chemicals in agriculture is limited by their insufficient control and variable efficacy when used alone, ways of combining them with other components to optimise their potential in the context of ICM is gaining evidence (Bruce et al. 2017; Yassin et al. 2021).

\section{New approaches to exploit genetic diversity: how best to deploy host resistance}

Ultimately, durable host plant disease resistance is perceived as the goal in disease management that would minimize the need for use of conventional plant protection chemistries. Much knowledge and many of the tools needed to introduce resistance to cultivated genotypes exists, including through conventional breeding approaches, and by biotechnology-based approaches of gene editing and gene silencing. However, these are not trivial approaches, and each takes many years to develop within a framework limited by existing knowledge, technology and legal or regulatory issues. A practical problem arises from the time consuming and labour intensive demands of host phenotyping. To overcome this constraint, new techniques involving optical sensors, artificial intelligence and machine 
learning have been proposed, "digital phenotyping" (Mahlein et al. 2019), which may have field application. The issue of durability is also strongly linked not just to the molecular and physiological responses to pathogen challenge, but to how resistance is deployed in host populations. Many questions still need attention. For example, from an evolutionary perspective, the costs of virulence may constrain the range of host genotypes a particular pathogen strain can adapt to and has implications for breeding for durable resistance and epidemiology (Laine and Barrès 2013).

Conventional breeding methods have been pivotal to obtain new plant genotypes with disease resistance traits to withstand epidemics, with major opportunities arising with new gene editing technologies (Pixley et al. 2019). However, while most plant breeding research as published in discipline-based journals focuses on the quantification of disease resistance and to elucidate its molecular basis, the interplay between resistant/ tolerant cultivars, cultural practices and climate conditions for disease management has been little explored. Although genetic markers for selection and breeding are routinely made available, can resistance be developed in time to manage emerging and invasive threats such as by targeting generic stress-response mechanisms (Newton et al. 2012)? The challenges in plant breeding are especially striking when considering tree crops which have slow growth and a long generation time (Boshier and Buggs 2015; Kelly et al. 2020; Showalter et al. 2020; Stocks et al. 2017). In these cases, the evaluation of the durability or resistance traits will take several decades.

Much neglected in the breeding of elite cultivars selected for performance under high input agronomy is their suitability for use in intercropping, but the resilience conferred by the diversity of intercropping is gaining considerable interest. In the former, resistance must be durable under the intense selection of a monoculture bred for self-competition. With intercropping, the range of epidemiological interactions available to a spatiotemporally diverse crop canopy can all be brought to bear on disease management. However, are the mechanisms sufficiently understood, how they work together, their genetic basis and whether classical approaches such as calculating general and specific combining ability are appropriate? We know that we can better exploit major gene resistance even within species by deploying genes in mixtures but how do we best exploit all types of resistance within and between species within intercropping (Fabre et al. 2015) and therefore how should we breed for such resistance? Or, to return to the earlier point, how best to breed crops for reduced vulnerability to pathogens.

\section{Promises and challenges for holobiont and microbiome research: an expanded perspective on microbial interactions, biological control, and disease management}

Across the animal and plant kingdoms, the holobiont' consists of a host and its associated microbiota, the 'microbiome' (Pitlik and Koren 2017). Disease can then be considered as arising from a perturbation of a healthy microbiome. The plant microbiome has received much attention over the last decade (Mercado-Blanco et al. 2018; Baldrian 2019; Vonaesch et al. 2018), in both food crops (Ding et al. 2019) and forest trees (Feau and Hamelin 2017; Koskella et al. 2017; Pinho et al. 2020). It has long been recognized that plant-associated microbiomes, the phytobiome (e.g., the phyllosphere, endophyte, and rhizosphere microbiome), will affect directly and/or indirectly disease development (Glaeser et al. 2019; Martin et al. 2019; Rabiey et al. 2019; Tsolakidou et al. 2019). Nevertheless, in much plant pathological research the focus remains on the action of individual pathogens in relation to climatic conditions and management methods on a susceptible host is usually the subject of study, but ignoring the complex resident microbiome in which a given disease is developing (Denman et al. 2018; Doonan et al. 2020). Microbial interactions including specific pathogens, such as in biocontrol research, are often studied yet the interactions have a high level of complexity (Zicca et al. 2020). However, in many microbial interaction studies, these are often restricted to interactions involving 2-3 organisms. The simplistic approach results primarily from: (1) a lack of efficient means of profiling the plant-associated microbiome, and (2) a lack of overall understanding of a pathogen's biology and epidemiology of the resulting disease, which can hinder the development of disease management strategies.

Recent advances in nucleic acid sequencing technologies have enabled the profiling of the microbiome of environmental samples. There are a growing number of published studies adding to our understanding of the effect of biotic and abiotic (including cultural management) factors on the plant-associated microbiome (Deakin et al. 2018; Peiffer et al. 2013; Schreiter et al. 2014; Wang et al. 2019). However, there remain difficulties including how to incorporate microbiome-related factors into plant disease epidemiological and management research. Firstly, how could the microbiome of a given sample be represented? Although many Operational Taxonomic Units (OTUs; often > 1000) are found in a sample, usually $<100$ of the OTUs account for most sequence reads. Many OTUs with very low counts could be a result of sequence errors, but how confidently can these minor OTUs be excluded from sample microbiome representation? Secondly, an OTU table from amplicon 
sequences only represents the relative frequencies of OTUs in each sample, when absolute microbial biomass/ counts may possibly be more important. It is possible that qPCR could be used to estimate the total microbial biomass via the generic fungal ITS and bacterial $16 \mathrm{~S}$ primers (e.g., Tilston et al. 2018). Alternatively, each environmental sample may be spiked with a known amount of a synthetic DNA fragment to estimate absolute abundance (Tkacz et al. 2018). Thirdly, there is not yet the reliable means to manipulate the plant-associated microbiome with predictable outcomes (Sessitsch et al. 2019). Therefore, it would be hard to ensure a homogeneous microbiome background whilst studying disease development. Finally, given the complexity of the microbiome, with many OTUs uncultivable as well as unidentifiable, it is difficult to conduct hypothesis-driven research on the interaction of a specific pathogen with one or more components of microbiomes. Solutions to these problems in the application of microbiome studies present challenges to be addressed. An ambitious objective in phytobiome research, integrating all factors which affect plant function, would be to "estimate the potential relative contribution of different components of the phytobiome to plant health, as well as the potential and risk of modifying each in the near future" (Bell et al. 2019). This objective effectively means taking a systems-level approach in which the microbial, environmental, macro-organism and plant management components are integrated with a potential role for generic crop modelling (Lamichhane et al. 2020).

\section{Disease surveillance, detection, and diagnosis}

A key challenge over the next decades is to develop tools and methodology that enable the rapid detection of disease outbreaks, especially those associated with novel or emerging plant pathogens, and the accurate diagnosis of the causal agents. This challenge can be met at the large scale by new surveillance techniques using monitoring networks (Hartmann et al. 2018), and at the small scale by new detection and diagnostic technologies made possible by new sequencing methodology. The fundamental challenge arises from integrating these technologies and approaches. Because of the change in scale from the molecular to the region, country or even continent, the challenge can only be met by a systems approach with an international dimension. Plant biosecurity is usually considered using the plant biosecurity continuum concept with trade surveillance and controls considered pre-border, at the border, and post-border (Gordh and McKirdy 2014). In an increasingly connected world this effectively brings the need for a global surveillance system, highlighting the need to access skills and technologies to increase baseline knowledge of pest and pathogen presence across the globe (MacDiarmid et al. 2013; Carvajal-Yepes et al. 2019).

\section{Issues for surveillance}

Automatic sensor technology has been used to supplement and, in some cases, replace conventional disease assessments and has the potential to be applied more widely under field conditions, whether in precision agriculture or host phenotyping (Mahlein et al. 2019; Bock et al. 2020). In that sense it enables surveillance of disease development at the field scale. One of the biggest challenges for any surveillance program occurs after a pest or pathogen has arrived and established in a new region or country. In these situations, early detection is vital for successful management and eradication, but it is often hard to achieve in large heterogeneous landscapes where host distributions may not be represented accurately, and causal agents may be novel. New technologies and working methods have great potential to improve detection. Remote sensing and scales from aerial imaging to satellite technology can identify the actions of individual pathogens in monocultures; for Xylella fastidiosa this can be achieved before symptoms are visible on the ground (Zarco-Tejada et al. 2018; Heim et al. 2019). When host distributions are more heterogeneous, for example, in native woodland, disease detection from imagery becomes a more complicated problem. Identifying host species accurately is a necessary precursor to disease detection and is not always possible, however the extent and locations of disturbances can still be accurately documented (Cohen et al. 2016).

A key challenge is early detection in the wider environment, how best to deploy technologies and integrate automated remote sensing with mass participation through stakeholder engagement. Technology, in the form of smart phone applications and web-based reporting, is also improving the ability of volunteers and land users to report signs of ill health in their crops and the wider environment. Such reports are best described as passive surveillance and often occur through citizen science programs (Dobson et al. 2020) but can also be made through a wider range of land users who report observations to the relevant authority (Meentemeyer et al. 2015; Brown et al. 2020). Observations collected through passive surveillance can provide vitally important first detections of new and emerging diseases but represent a challenge to analysts and modelers due to their unstructured nature. They are made when an observer both notices something of concern and decides to make a report, as such records can be described as messy and may contain biases that affect the accuracy of predictions (August et al. 2020). Techniques to identify and correct for biases in citizen science programs and the data bases that result have been 
reported (Baker et al 2019). Citizen science programs can be designed to improve detection and increase awareness of plant health problems, an example of this process can be found in Colorado, US, where volunteers are asked to help map host (ash tree) distributions in advance of pest arrival (Agrilus planipennis) (Alexander et al. 2020). The role of land user and stake holder participation in the detection and management of plant health issues is a key area for future research (Brown et al. 2017; Milne et al. 2020) as their decisions can influence the outcome of management and eradication programs: an issue found to be of considerable importance for tree crops in the UK (Marzano et al. 2015, 2019).

\section{Issues for diagnostics}

Early in the high-throughput sequencing (HTS) era, MacDiarmid et al. (2013) made three recommendations for the challenges posed by this new diagnostics technology, especially concerning plant viruses: (1) countries should baseline what pests were present in their territory and had a burden of proof for demonstrating risk of novel findings before implementing plant health action; (2) viruses not associated with disease should get special designation; and (3) there was a need for funding in areas of basic research such as virus ecology and to develop host-virus pathogenicity prediction tools. Several years later the biggest challenge for HTS diagnostics arguably still lies in its own success, in terms of the numerous novel and unusual pathogens (mainly viruses) being discovered (Villamor et al. 2019). HTS is revolutionizing the diagnostics workflow in the laboratory with applications ranging from single sample diagnostics and answering decades old questions of disease etiology through to population studies and supporting plant trade by being able to declare the material free from pathogens (Maree et al. 2018). However, as a technology which has been exploited for more than a decade in virus research, the routine adoption of this technology, especially in frontline diagnostic applications and with fungal and bacterial pathogens, has lagged. This is due to key blockers such as costs, validation, processing and handling large volumes of data, and probably most crucially, how to handle the risk assessment of novel discoveries (Olmos et al. 2018; Massart et al. 2017). In this respect, the double-edged sword of HTS based diagnostics is very much worth exploring, as the other plant pathology disciplines are shortly to realize the issues the virologists have been wrestling with over the last decade. The main challenge remains determining the link between the viruses inferred from sequence data and the symptoms of disease which led to the sample being sequenced, and consequently allow inferences to be made on the potential impact of these pathogens (Fox 2020).

The complications of interpreting HTS data in frontline diagnostics go beyond causation and feeding this forward into assessing the risk of the new, unusual, and mixed infections is now being encountered with a degree of regularity. Massart et al. (2017) put forward a framework for evaluating the risk of new virus detections, but this was very much based on singular detections and would be difficult to apply to complex infections or polymicrobial diseases. For example, the suggested approach of infectious clone work as a means of overcoming causation questions may not be practical given the volume of new findings and the potential for complex infection interactions. The added complication of confounding factors such as environmental influences and timing of infection to symptom development also requires a more holistic approach. A predictive approach was suggested by Babayan et al. (2018) for mammalian arboviruses, but there would be challenges in applying this to plant viruses. Not least of these is the relative lack of information on host range and transmission for many plant viruses by comparison to their mammalian-infecting counterparts. Also spanning this whole area is the lack of centralized information on plant viruses given the neglect of online resources such as the Plant Virus Online VIDE-database and the AAB Descriptions of plant viruses, leaving the resources such as CABI datasheets and the EPPO Global Database as the main sources of information, which whilst useful lack search functionality for some hosts and their distribution, and would hamper any attempts to start gathering this type of data for analysis.

There is also the challenge of tying together the discoveries of the pre-sequencing and post-sequencing eras. There are many examples of viruses and 'viruslike- agents' discovered in the mid-to-late twentieth century which had been described based on their biological, serological and physiochemical properties for which no sequence data exist. Many of these pathogens have been included in plant health regulations around the globe, and some are even recognized as species. However, with the increased use of non-targeted sequence-based detection, combined with the limited resources available for time consuming and costly biological characterization work there are examples of 'rediscovery', such as the case of plantain virus $\mathrm{X}$ and Actinidia virus $\mathrm{X}$, two synonymous viruses discovered at opposite sides of the globe, over 30 years apart, and in unrelated hosts (Hammond et al. 2020), a case study pulling together two recognized species discovered $30+$ years apart (pre and post sequencing eras) where the conclusions being drawn on the risk of the latter were incorrect due to lack of knowledge on the first non-sequenced report. Historic isolate 
collections can be an invaluable resource. Such historic isolates allow support for risk assessment though baselining for presence and host range and for informing evolutionary studies (Jones et al. 2020).

On top of these issues, there is the question of scale, which links detection and diagnostic technology with the surveillance issues noted above. As the technology gets applied for area and landscape scale studies, these issues will be further compounded by a lack of samplespecific contextual data, which must be considered during experimental design or surveillance schemes. Whilst HTS technologies offer unparalleled diagnostic potential, for these approaches to be routinely applied issues such as provision of validation data to demonstrate the performance characteristics of the platforms and open sharing of data and research coordination need to be added to the outstanding items on the original list discussed by MacDiarmid et al. (2013). Can pathogen risk factors be identified from HTS inferred sequences?

\section{Exotic and re-emerging pathogens}

A current and burgeoning challenge for the discipline of plant pathology is the introduction and spread of pathogens to new locations, and emergence or re-emergence of new pathogens against a background of a changing climate (Sumner 2003; Garbelotto and Pautasso 2012; Gottwald et al. 2019; Carvajal-Yepes et al. 2019). The rate of transfer of plant material both as traded commodity and as living material for planting or breeding purposes has accelerated over the last several decades. As a result, exotic plant diseases have become more prevalent and problematic in agricultural and natural systems throughout the world, to the point of developing recovery plans to potential risks posed by some pathogens (McRoberts et al. 2016). From a plant health perspective there is a gap between non-native pathogens intercepted on a regular basis and those which go on to establish in a region. This gap is complex and poorly understood with a range of influencing factors including climate and host suitability, but also understanding pathways e.g., fruit going to market as opposed to seeds or plants for planting. For a challenge-better understanding of this gap may allow for better targeting of resources to the pathogen/trade pathways presenting the greatest risk?

The trend in exotic plant disease is likely to increase as international travel, trade, and societal unrest (Hulme 2009) continue to provide opportunities for pathogen dispersal. Identifying new outbreaks is challenging as often the disease may already be quite widespread when first identified, for example, with HLB (Candidatus Liberibacter asiaticus) in Florida in 2005 (Halbert 2005; Gottwald et al. 2007). Tracking spread also requires a rapid and effective response to be effective. Quarantine, using sentinel trap plants, molecular diagnostics or canines to detect an organism may all currently be used, but the challenge to develop novel tools that may be part of early detection, warning and management to increase the effectiveness of dealing with exotic diseases is a challenge (Gottwald et al. 2019). Also managing a disease once identified may require complex coordination of resources and the support of local communities, and the environment, that can otherwise derail eradication efforts as happened with citrus canker in Florida (Gottwald et al. 2002; Gochez et al. 2020). Research to establish the pathogen spread, survival and dispersal of propagules using existing and novel tools will be paramount to minimize impact of exotic pathogens. A challenge is to develop effective predictive models that will aid early detection and perhaps allow placement and integration of early detection systems (Pautasso 2013). Understanding the genetic basis for any changes in populations of exotic or re-emerging pathogens will similarly be critical to identify any reasons for changes in patterns of the epidemic and thus responding appropriately (Grunwald and Goss 2011). Additionally, risks are posed by unregulated trade and 'exotic' hosts. Current formal phytosanitary systems pick up pathogens on formal trade routes either before or after entry (VanDersal 2007; Fox and Mumford 2017). However, new trade routes and patterns, informal trade especially through internet sales may be more difficult to police even with novel diagnostics (Giltrap et al. 2009; Kaminski et al. 2012; Fox et al. 2019). Can methods (both regulatory and technological) be developed that can encompass the needs of more conventional trade, and these more recent and difficult-to-track trade networks?

If not detected prior to introduction, eradication of exotic diseases should remain the goal and developing effective eradication programs will continue to be challenging against an ever more mobile society, transferring more diverse material that may not be strictly regulated, and by individuals who may have conflicting personal or political priorities or interests. Regulatory measures play a major role in preventing those introductions as well as controlling established outbreaks through eradication or containment. The implementation of regulatory measures is often associated with trade disputes and social concerns, sometimes leading to delayed or even halted interventions (Marzano et al. 2015). Exploring the socio-economic dimensions of regulatory disease control would be a productive cross-discipline exercise. The plant pathology discipline faces challenges to provide the tools to the regulatory agencies to detect the pathogen and/or exotic and re-emerging plant diseases at the earliest stage possible, and subsequently to develop rapidly, more effective eradiation and disease management plans that are achievable within the socio-economic limitations. 


\section{Climate change}

Climate change has already, and increasingly, will affect the prevalence and frequency of different plant diseases across a spectrum of important staple and specialty crops, and in natural ecosystems (Garrett 2008; Chakraborty et al. 2008; Chakraborty and Newton 2011; Pautasso et al. 2012; Elad and Pertot 2014; Burdon and Zhan. 2020). Predicting the future impacts of climate change on plant disease is not a simple matter. Unexpected and possibly unpredictable impacts may arise due to the interactions of climate change with other factors, including shifts in host range, changes in agricultural intensification, introductions of exotic pathogens, and genetic events (Corredor-Moreno and Saunders 2020). The factors that affect climate change impact can be categorized in terms of 'risk mitigation' and 'risk enhancement' (Fig. 2 in Chakraborty and Newton, 2011) recognizing that mitigating and enhancing influences are the result of complex interactions among these 'remediating' and 'enhancing' influences. Multiple components of these interactions (pathogens, crops, vectors, natural enemies, microbiome) are influenced by climatic variables in different ways. The challenge is to determine the relative importance of the biological processes and the key climatic influences together to predict the likely impact of climate change on production systems in time and space. An increasing number of climate related epidemics have been characterized. The example of Phytophthora ramorum (cause of sudden oak death) in North America and Europe being particularly well described in terms of invasive nature and likely anticipated spread due to a changing climate. Factors associated with both the host pathogen interaction and availability of inoculum may affect spread and incidence of the disease. Warmer, drier, or wetter conditions may all influence the host and/ or pathogen, or the interaction in ways that may increase, or reduce the effect of the disease on a plant host. Phoma stem canker of oilseed rape in the UK was increased due to earlier epidemic development due to milder seasons. Interactions between climate warming and pathogen biology is likely to produce differential effects on diseases in different climatic zones. For Austropuccina psidii (myrtle rust), an invasive species of subtropical origin, climate warming is expected to increase disease in temperate areas through increased annual frequency of conditions favourable for the pathogen infection cycle. Conversely, in the tropics, longer periods above the maximum temperature for infection and latent development may reduce the risk of disease (Beresford et al. 2020).

Furthermore, encompassing pollutants changes in composition of the atmosphere other than just carbon dioxide appears to also impact pathogens, as with the change in relative abundance of the cereal pathogens Phaeosphaeria nodorum and Mycosphaerella graminicola (Zymoseptoria tritici) in the UK attributed to sulphur dioxide (Fitt et al. 2011). This study emphasized the value of long-term data sets in interpreting past trends in pathogen prevalence (Jeger and Pautasso 2008) and in host abundance in natural plant communities (Salama et al. 2012). At the landscape scale, deposition of atmospheric pollutants including nitrogen and sulphur, have also been identified as potential predisposing factors underlying oak decline (Brown et al. 2018), with nitrogen imbalance and differing abundance of nitrogen cycling microorganisms observed at the tree level (Scarlett et al., 2020).

The economic and environmental impact of specific diseases in different regions will likely shift over the coming decades and the range of pathogens able to infect a host species will similarly shift, which will be a challenge to monitor. This shift will present challenges to the producers of crops and stewards of natural ecosystems as existing or novel methods for disease management will need to be transferred or developed by plant pathologists and implemented against a background of stringent disease control regulation. How effective will some management strategies such as biological control be in a shifting climate? Research will be challenged to better understand how climate shifts will affect existing pathogen life cycles and survival, host susceptibilities and host pathogen interactions. A continuing challenge to phytosanitary organizations will be the requirement for novel tools to address changes in presence and abundance of pathogens. This includes identifying threats now posed by pathogens from exotic locales due to shifts in climate in other areas where conditions may become conducive to invasion.

Understanding the underlying condition of host plants, especially in natural environments is therefore a crucial component to understanding pest and disease impacts and stresses the contextual information necessary for effective disease surveillance. The effect of drought and other disturbances on forested ecosystems has been dramatic, with wide scale dieback and decline (Choat et al. 2012, 2018; Millar and Stephenson 2015; Seidl et al. 2020). The role of pest and pathogens in tree mortality in low rainfall conditions is poorly understood (Stovall et al. 2020) and integrated research and monitoring is needed to reveal the extent of the affected areas and the mechanisms that underpin mortality (Hartmann et al. 2018). Changes to silvicultural systems have been proposed as a means of climate change adaptation (Bradford and Bell 2017). 


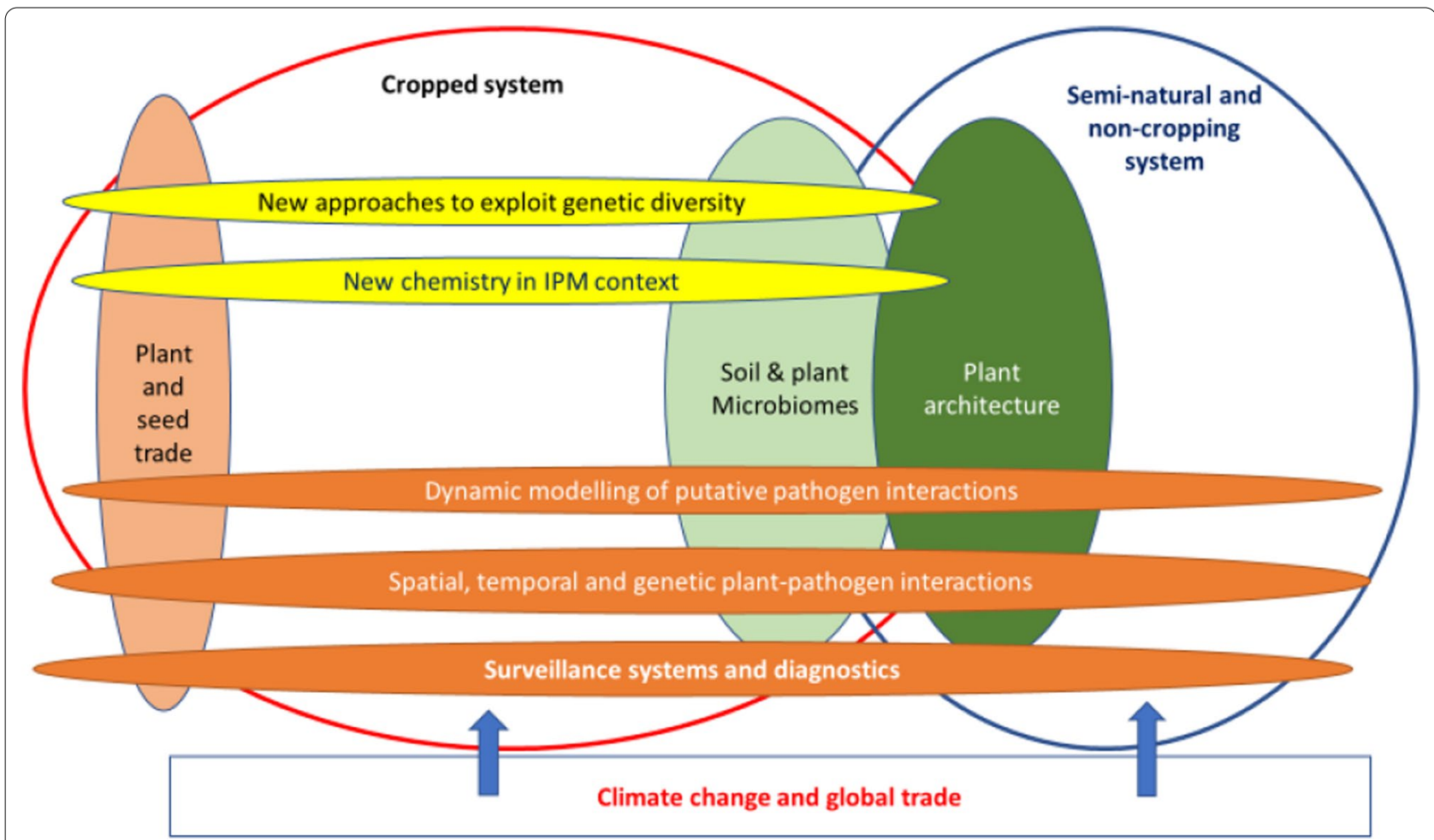

Fig. 3 Schematic showing how the interlocking of different strands of multidisciplinary research in plant pathology should develop to meet the cropping, food security and environmental challenges of the coming decades. The diagram shows the continuum between cropped and non-cropped systems. Genetic and plant chemistry research will contribute from seed to mature plant performance. An understanding and management of host-pathogen interactions and epidemiology will benefit from research across the continuum. Climate change and the global trade in commodities will drive the introduction and spread of exotic pathogens into both cropped and non-cropped systems with the concomitant need for improved and linked surveillance and diagnostic systems. In all areas of research there should be a role for social scientists and other concerned participants in research scoping, planning and implementation

\section{Conclusions}

This review has been wide-ranging and identified some key challenges and opportunities for plant pathology research over the next few decades by emphasizing the inter- and cross-disciplinary links with other disciplines in the agricultural and environmental sciences. We acknowledge that the scale and change in research emphasis we recommend will require changes in the current model for research funding, especially where immediate solutions to pressing problems are required by research funders. Also, the structure of academic research institutions and the types of incentives and recognition systems that are often in place counter-indicate the change in emphasis we envisage.

Despite this important qualification, we have attempted to pull together these links across the topics which form the structure of this review in Fig. 3. To re-iterate, this is not to say that conceptual, methodological, and technological developments within the discipline do not also present their own challenges and opportunities, but that is not the emphasis here. The key conclusions we draw are:

- Changes in cropping systems and wild plant communities will be multifactorial, meaning that the causes and consequences of plant diseases in these systems must be seen from a whole system perspective.

- Interactions of pathogen life stages with varying organ susceptibility during plant development need to be understood as part of the whole system. Integration of disease models into crop growth models offers a way to quantify how pathogen-crop interactions, including yield effects and inoculum production, and could pave the way for quantitative understanding of more complex interactions between host plants, their pathogens and other microbiome components.

- Canopy (and root system) architecture will be a greater consideration in designing and breeding new varieties for agronomic objectives; the implica- 
tions must be accounted for in the development of new disease and pest management strategies.

- There are different genetic, spatial, and temporal dimensions to diversity and their potential exploitation in crop and environmental management. This applies not just in host and pathogen populations, but in soils and associated microbiota, tillage, and the use of trap plantings in crop protection.

- New chemistries as well as the more effective exploitation of chemical induced resistance agents or resistance elicitors may have the potential to offer more benign and sustainable disease control interventions. How will these chemistries interact with plant responses to multiple pathogens and pests?

- The microbiome concept has revolutionized the ways in which microbial interactions with plants and in the environment are perceived but may lead to a switch away from the ideal of hypothesis-driven research. The potential relevance to disease management is clear but needs to be realized.

- Improved remote sensing technologies are being developed that can be used at different scales. Similarly, more informal systems of mass surveillance, including citizen science, are gaining traction because of the savings in costs and associated resources. Methods need to be developed to integrating these two approaches to surveillance.

- Specificity and sensitivity of new sequencing diagnostic techniques raise new problems in interpretation. This has been most apparent with plant viruses but will be faced by other disciplines within plant pathology. The use of diagnostic facilities must be linked with the contextual information obtained from surveillance.

- There is every indication that trade in plants will continue at a global scale, and that human mobility will increase due to business, leisure, migration, and social disruption. The challenges to disease and pest management will accordingly increase. Options to meet these challenges will include placement of sentinel plantings for surveillance or pathogen detection systems in trade networks but will require a continuing and strengthened international cooperation.

- Climate change, mitigation and adaptation have received much attention in relation to crop diseases and pests. An area that has received less attention is the effects on wild plant communities whether in relation to the impacts of novel pathogen encounters or through their underlying responses to climate change.

\section{Abbreviations}

AAB: Association of applied biologists; APSIM: Agricultural production systems simulator; EPPO: European and Mediterranean Plant Protection Organization; HLB: Huanglongbing disease of citrus; HTS: High throughput sequencing; ICM: Integrated crop management; ITS: Internal transcribed spacer; IPM: Integrated pest management; IPPC: International Plant Protection Convention; OTU: Operational taxonomic unit; VIDE: Virus identification data exchange.

\section{Acknowledgements \\ Not applicable.}

\section{Authors' contributions}

The authors contributed equally to the writing of this manuscript. All authors read and approved the final manuscript.

\section{Authors' information}

$\mathrm{MJJ}$ is Section Editor, other authors are Associate Editors, of CABI Agriculture and Bioscience.

\section{Funding}

ACN is grateful for funding from the Scottish Government Rural and Environment Science and Analytical Services (RESAS).

Availability of data and materials

Not applicable.

\section{Declarations}

Ethics approval and consent to participate

Not applicable.

\section{Consent for publication}

Not applicable.

\section{Competing interests}

The authors declare they have no competing interests.

\section{Author details}

${ }^{1}$ Imperial College London, London, UK. ${ }^{2}$ The New Zealand Institute for Plant \& Food Research Ltd, Auckland, New Zealand. ${ }^{3}$ USDA Agricultural Research Service, Washington, USA. ${ }^{4}$ Woodland Heritage, Cheltenham, UK. ${ }^{5}$ Fera Science Ltd., Sand Hutton, UK. ${ }^{6}$ The James Hutton Institute, Dundee, Scotland. ${ }^{7}$ Institut Valencià D'Investigacions Agràries (IVIA), Valencia, Spain. ${ }^{8}$ East Malling Research, West Malling, UK. ${ }^{9}$ Swedish University of Agricultural Sciences, Uppsala, Sweden.

Received: 19 December 2020 Accepted: 14 May 2021

Published online: 26 May 2021

\section{References}

Agrios GN. Plant pathology. 5th ed. San Diego: Elsevier; 2005.

Alexander K, Truslove M, Davis R, Stephens S, Zentz RA. Collaborative approach to preparing for and reacting to emerald ash borer: a case study from Colorado. Forestry. 2020;93:239-53.

Asalf B, Gadoury DM, Tronsmo AM, Seem RC, Dobson A, Peres NA, Stensvand A. Ontogenic resistance of leaves and fruit, and how leaf folding influences the distribution of powdery mildew on strawberry plants colonized by Podosphaera aphanis. Phytopathology. 2014;104:954-63.

Atkins SD, Fitt BDL, Fraaije B, Harvey S, Lynott J, Newton AC. The epidemiological importance of asymptomatic infection of winter barley by Rhynchosporium secalis and its consequences for crop protection and breeding. The Dundee Conference. Crop Protection in Northern Britain 2010, Dundee, UK, 23-24 Feb 2010. p.81-6.

August TA, Fox R, Roy DB, Pocock MJO. Data-derived metrics describing the behaviour of field-based citizen scientists provide insights for project design and modelling bias. Sci Rep. 2020;10:11009. 
Avelino J, Allinne C, Cerda R, Willocquet L, Savary S. Multiple-disease system in coffee: from crop loss assessment to sustainable management. Annu Rev Phytopathol. 2018;56:611-35.

Babayan SA, Orton RJ, Streicker DG. Predicting reservoir hosts and arthropod vectors from evolutionary signatures in RNA virus genomes. Science. 2018;362:577-80.

Baker E, Jeger MJ, Mumford JD, Brown N, et al. Enhancing plant biosecurity with citizen science monitoring: comparing methodologies using reports of acute oak decline. J Geog Syst. 2019;21:111-31.

Baldrian P. The known and the unknown in soil microbial ecology. FEMS Microbiol Ecol. 2019;9:fiy227.

Bell TH, Hockett KL, Alcalá-Briseño RI, Barbercheck M, Beattie GA, Bruns MA, Carlson JE, et al. Manipulating wild and tamed phytobiomes: challenges and opportunities. Phytobiomes. 2019;3:3-21.

Beresford RM, Henshall WR, Palmer JW. A new apple scab risk model that integrates ascospore release, infection risk and susceptible leaf area. NZ Plant Prot. 2004;57:20-4

Beresford RM, Shuey LS, Pegg GS. Symptom development and latent period of Austropuccinia psidii (myrtle rust) in relation to host species, temperature and ontogenic resistance. Plant Pathol. 2020;2020(69):484-94.

Blanco-Ulate B, Vincenti E, Cantu D, Powell A. Ripening of tomato fruit and susceptibility to Botrytis cinerea. In: Fillinger S, Elad Y, editors. Botrytisthe fungus, the pathogen and its management in agricultural systems. New York: Springer; 2016. p. 387-412.

Bock CH, Barbedo JGA, Del Ponte EM, Bohnenkamp D, Mahlein A-K. From visual estimates to fully automated sensor-based measurements of plant disease severity: status and challenges for improving accuracy. Phytopathol Res. 2020;2:9.

Boshier D, Buggs RJA. The potential for field studies and genomic technologies to enhance resistance and resilience of British tree populations to pests and pathogens. Forestry. 2015:88:27-40.

Bowen JK, Mesarich CH, Bus VGM, Beresford RM, Plummer KM, Templeton MD. Venturia inaequalis: the causal agent of apple scab. Mol Plant Pathol. 2011;12:105-22

Bradford JB, Bell DM. A window of opportunity for climate-change adaptation: easing tree mortality by reducing forest basal area. Front Ecol Environ. 2017;15:11-7

Brent KJ, Holloman DW. Fungicide resistance in crop pathogens: how can it be managed? FRAC monograph No. 1. 2nd ed. Brussles: Fungicide Resistance Action Committee; 2007.

Brown N, van den Bosch F, Parnell S, Denman S. Integrating regulatory surveys and citizen science to map outbreaks of forest diseases: acute oak decline in England and Wales. Proc R Soc B. 2017;284:20170547.

Brown N, Vanguelova E, Parnell S, Broadmeadow S, Denman S. Predisposition of forests to biotic disturbance: predicting the distribution of acute oak decline using environmental factors. Forest Ecol Man. 2018:407:145-54.

Brown N, Pérez-Sierra A, Crow P, Parnell S. The role of passive surveillance and citizen science in plant health. CABI Agric Biosci. 2020;1:17.

Bruce TJA, et al. Prospects for plant defence activators and biocontrol in IPMconcepts and lessons learnt so far. Crop Prot. 2017;97:128-34.

Burdon JJ, Zhan J. Climate change and disease in plant communities. PLoS Biol. 2020;18:e3000949.

Carvajal-Yepes M, Cardwell K, Nelson A, Garrett KA, Giovani B, Saunders DGO, Kamoun S, et al. A global surveillance system for crop diseases: global preparedness minimizes the risk to food supplies. Science. 2019;364:1237-9.

Chakraborty S, Newton AC. Climate change, plant diseases and food security: an overview. Plant Pathol. 2011:60:2-14.

Chakraborty S, Luck J, Hollaway G, Freeman A, Norton R, Garrett KA, et al. Impacts of global change on diseases of agricultural crops and forest trees. CAB Rev. 2008;3:54.

Cheatham MR, Rouse MN, Esker PD, Ignacio S, Pradel W, Raymundo R, Sparks $\mathrm{AH}$, et al. Beyond yield: plant disease in the context of ecosystem services. Phytopathology. 2009;99:1228-36.

Choat B, Jansen S, Brodribb TJ, Cochard H, Delzon S, Bhaskar R, et al. Global convergence in the vulnerability of forests to drought. Nature. 2012;491:752-5.

Choat B, Brodribb TJ, Brodersen CR, Duursma RA, López R, Medlyn BE. Triggers of tree mortality under drought. Nature. 2018:558:531-9.

Cohen WB, Yang Z, Stehman SV, Schroeder TA, Bell DM, Masek JG, et al. Forest disturbance across the conterminous United States from
1985-2012: the emerging dominance of forest decline. Forest Ecol Man 2016;360:242-52.

Corredor-Moreno P, Saunders DGO. Expecting the unexpected: factors influencing the emergence of fungal and oomycete plant pathogens. New Phytol. 2020;225:118-25.

Costes E, Lauri PE, Simon S, Andrieu B. Plant architecture, its diversity and manipulation in agronomic conditions, in relation with pest and pathogen attacks. Eur J Plant Pathol. 2013;2013(135):455-70.

De Wolf ED, Isard SA. Disease cycle approach to plant disease prediction. Annual Rev Phytopathol. 2007;45:203-20.

Deakin G, Tilston EL, Bennett J, Passey T, Harrison N, Fernández-Fernández F, Xu $X-M$. Spatial structuring of soil microbial communities in commercial apple orchards. Appl Soil Ecol. 2018;130:1-12.

Denman S, Doonan J, Ransom-Jones E, Broberg M, Plummer S, Kirk S, et al. Microbiome and infectivity studies reveal complex polyspecies tree disease in acute oak decline. ISME J. 2018;12:386-99.

Develey-Rivière M, Galiana E. Resistance to pathogens and host developmental stage: a multifaceted relationship within the plant kingdom. New Phytol. 2007;175:405-16.

Ding L-J, Cui H-L, Nie S-A, Long X-E, Duan G-L, Zhu Y-G. Microbiomes inhabiting rice roots and rhizosphere. FEMS Microbiol Ecol. 2019;95:fiz040.

Dobson ADM, Milner-Gulland EJ, Aebischer NJ, Beale CM, Brozovic R, Coals $P$, et al. Making messy data work for conservation. One Earth. 2020;2:455-65.

Doonan J, Broberg M, Denman S, McDonald JE. Host-microbiota-insect interactions drive emergent virulence in a complex tree disease. Proc R Soc B. 2020. https://doi.org/10.1098/rspb.2020.0956 (in press).

Elad Y, Pertot I. Climate change impacts on plant pathogens and plant diseases. J Crop Impr. 2014;28:99-139.

Fabre F, Rousseau E, Mailleret M, Moury B. Epidemiological and evolutionary management of plant resistance: optimizing the deployment of cultivar mixtures in time and space in agricultural landscapes. Evol Appl. 2015;8:919-32.

Feau N, Hamelin RC. Say hello to my little friends: how microbiota can modulate tree health. New Phytol. 2017;215:508-10.

Ficke A, Gadoury DM, Seem RC, Dry I. Effects of ontogenic resistance upon establishment and growth of Uncinula necator on grape berries. Phytopathology. 2003;93:556-63.

Fitt BDL, Fraaije BA, Chandramohan P, Shaw MW. Impacts of changing air composition on severity of arable crop disease epidemics. Plant Pathol. 2011;60:44-53.

Fox A. Reconsidering causal association in plant virology. Plant Pathol. 2020;69:956-61.

Fox A, Mumford RA. Plant viruses and viroids in the United Kingdom: an analysis of first detections and novel discoveries from 1980 to 2014. Virus Res. 2017;241:10-8.

Fox A, Fowkes AR, Skelton A, Harju V, Buxton-Kirk A, Kelly M, Forde SMD, Pufal $\mathrm{H}$, Conyers C, Ward R, Weekes R. Using high-throughput sequencing in support of a plant health outbreak reveals novel viruses in Ullucus tuberosus (Basellaceae). Plant Pathol. 2019;68:576-87.

Froud KJ, Everett KE, Tyson JL, Beresford RM, Cogger N. Review of the risk factors associated with kiwifruit bacterial canker caused by Pseudomonas syringae pv. actinidiae. NZ Plant Prot. 2015;68:313-27.

Garbelotto M, Pautasso M. Impacts of exotic forest pathogens on Mediterranean ecosystems: four case studies. Eur J Plant Pathol. 2012;133:101-16.

Garcia-Figuera S, Grafton-Cardwell EE, Babcock BA, Lubell MN, McRoberts N. Institutional approaches for plant health provision as a collective action problem. Food Sec. 2021. https://doi.org/10.1007/s12571-020-01133-9.

Garrett KA. Climate change and plant disease risk. In: Relman DA, Hamburg MA, Choffnes ER, Mack A, editors. Global climate change and extreme weather events understanding the contributions to infectious disease emergence. Washington, DC: National Academies Press; 2008. p. 143-55.

Gent DH, Mahaffee WF, McRoberts N, Pfender WF. The use and role of predictive systems in disease management. Annu Rev Phytopathol. 2013:51:267-89.

Gill SS, Gill R, Trivedi DK, Anjum NA, Sharma KK, Ansari MW, Ansari AA, Johri AK, Prasad R, Pereira E, Varma A, Tuteja N. Piriformospora indica: potential and significance in plant stress tolerance. Front Microbiol. 2016;7:332.

Giltrap N, Eyre D, Reed P. Internet sales of plants for planting —an increasing trend and threat? EPPO Bull. 2009:39:168-70. 
Glaeser SP, Gabur I, Haghighi H, Bartz J-O, Kämpfer P, Snowdon R, et al. Endophytic bacterial communities of oilseed rape associate with genotypespecific resistance against Verticillium longisporum. FEMS Microbiol Ecol. 2019;96:fiz188.

Gochez AM, Behlau F, Singh R, et al. Panorama of citrus canker in the United States. Trop Plant Pathol. 2020;45:192-9.

Gordh G, McKirdy S. The handbook of plant biosecurity. New York: Springer; 2014.

Gottwald TR, Graham JH, Schubert TS. Citrus canker: the pathogen and its impact. Plant Health Progr. 2002. https://doi.org/10.1094/PHP-20020812-01-RV (Online).

Gottwald TR, da Graça JV, Bassanezi RB. Citrus Huanglongbing: the pathogen and its impact. Plant Health Progr. 2007. https://doi.org/10.1094/PHP2007-0906-01-RV (Online).

Gottwald TR, Luo W, Posny D, Riley T, Louws F. A probabilistic census-travel model to predict introduction sites of exotic plant, animal and human pathogens. Phil Trans R Soc B. 2019;374:20180260.

Grammen A, Van Campenhout J, Geeraerd A, Keulemans W. Susceptibility of apple fruits (Malus $\times$ domestica Borkh.) to the postharvest pathogen Colletotrichum fioriniae: cultivar differences and correlation with fruit ripening characteristics. Eur J Plant Pathol. 2019;155:801-16.

Grunwald NJ, Goss EM. Evolution and population genetics of exotic and re-emerging pathogens: novel tools and approaches. Annu Rev Phytopathol. 2011;49:249-67.

Halbert SE. The discovery of huanglongbing in Florida. In: proceedings of the international citrus canker and huanglongbing research workshop, Orlando, H-3, 2005; p. 50.

Hammond J, Adams IP, Fowkes AR, McGreig S, Botermans M, van Oorspronk JJA, Westenberg M, Verbeek $M$, et al. Sequence analysis of 43-year old samples of Plantago lanceolata show that Plantain virus $X$ is synonymous with Actinidia virus X and is widely distributed. Plant Pathol. 2020. https://doi.org/10.1111/ppa.13310 (Online).

Hartmann H, Moura CF, Anderegg WRL, Ruehr NK, Salmon Y, Allen CD, et al. Research frontiers for improving our understanding of droughtinduced tree and forest mortality. New Phytol. 2018;218:15-28.

Hawkins NJ, Fraaije BA. Fitness penalties in the evolution of fungicide resistance. Annu Rev Phytopathol. 2018;56:339-60.

Heim RHJ, Carnegie AJ, Zarco-Tejada PJ. Breaking down barriers between remote sensing and plant pathology. Trop Plant Pathol. 2019:44:398-400

Hitaj C, Smith DJ, Code A, Wechsler S, Esker PD, Douglas MR. Sowing uncertainty: what we do and don't know about the planting of pesticidetreated seed. Bioscience. 2020;70:390-403.

Hollomon DW. Fungicide resistance: facing the challenge-a review. Plant Protect Sci. 2015;51:170-6.

Hulme PE. Trade, transport and trouble: managing invasive species pathways in an era of globalization. J Appl Ecol. 2009;46:10-8.

Ilbery B, Maye D, Little R. Plant disease risk and grower-agronomist perceptions and relationships: an analysis of the UK potato and wheat sectors. Appl Geog. 2012;34:306-15.

Jactel H, Desprez-Loustau M-L, Battisti A, Brockerhoff E, Santini A, Stenlid J, et al. Pathologists and entomologists must join forces against forest pest and pathogen invasions. NeoBiota. 2020;58:107-27.

Jeger MJ. Analysis of disease progress as a basis for evaluating disease management practices. Annu Rev Phytopathol. 2004;42:61-82.

Jeger MJ. Disease in deciduous fruit production. In: Tromp J, Webster AD, Wertheim SJ, editors. Fundamentals of temperate zone tree fruit production. Leiden: Backhuys Publishers; 2005. p. 359-71.

Jeger MJ, Pautasso M. Plant disease and global change-the importance of long-term data sets. New Phytol. 2008;177:8-11.

Jones RAC, Boonham N, Adams IP, Fox A. Historical virus isolate collections: an invaluable resource connecting plant virology's pre-sequencing and post-sequencing eras. Plant Pathol. 2020. https://doi.org/10.1111/ppa. 13313 (Online)

Kaminski K, Beckers F, Unger JG. Global internet trade of plants-legality and risks. EPPO Bull. 2012;42:171-5.

Keating BA, Carberry PS, Hammer GL, Probert WE, Robertson MJ, Holzworth D, Huth NI, Hargreaves JNG, Meinke H, Hochman Z, McLean G, Verburg K, Snow V, Dimes JP, Silburn M, Wang E, Brown S, Bristow KL, Asseng S, Chapman S, McCown RL, Freebairn DM, Smith CJ. An overview of
APSIM, a model designed for farming systems simulation. Eur J Agron. 2003;18:267-328.

Kelly LJ, Plumb WJ, Carey DW, Mason ME, Cooper ED, Crowther W, et al. Convergent molecular evolution among ash species resistant to the emerald ash borer. Nat Ecol Evol. 2020;4:1116-28.

Kitchen NR. Emerging technologies for real-time and integrated agriculture decisions. Comp Electron Agric. 2008;61:1-3.

Koskella B, Meaden S, Crowther WJ, Leimu R, Metcalf CJE. A signature of tree health? Shifts in the microbiome and the ecological drivers of horse chestnut bleeding canker disease. New Phytol. 2017;215:737-46.

Kristoffersen R, Marten Heick T, Müller GM, Eriksen LB, Nielsen GC, Jørgensen $L N$. The potential of cultivar mixtures to reduce fungicide input and mitigate fungicide resistance development. Agron Sustain Devel. 2020;40:36

Laine AL, Barrès B. Epidemiological and evolutionary consequences of lifehistory trade-offs in pathogens. Plant Pathol. 2013;62:96-105.

Lamichhane JR, You MP, Barbetti MJ, Aubertot J-N. Crop Establishment SIMulator: a qualitative aggregative model to predict the role of phytobiomes on field crop establishment. Phytobiomes J. 2020;4:327-39.

Li B, Xu X-M. Infection and development of apple scab (Venturia inaequalis) on old leaves. J Plant Pathol. 2008;150:687-91.

MacDiarmid R, Rodoni B, Melcher U, Ochoa-Corona F, Roossinck M. Biosecurity implications of new technology and discovery in plant virus research. PLOS Pathog. 2013;9:e1003337.

Mahlein A-K, Kuska MT, Thomas S, Wahabzada M, Behmann J, Rascher U, Kersting K. Quantitative and qualitative phenotyping of disease resistance of crops by hyperspectral sensors: seamless interlocking of phytopathology, sensors, and machine learning is needed. Curr Opin Plant Biol. 2019;50:156-62.

Mankad A. Psychological influences on biosecurity control and farmer decision-making. A review. Agron Sust Dev. 2016;2016(36):40.

Maree HJ, Fox A, Al Rwahnih M, Boonham N, Candresse T. Application of HTS for routine plant virus diagnostics: state of the art and challenges. Front Plant Sci. 2018;9:1082.

Martin BC, Alarcon MS, Gleeson D, Middleton JA, Fraser MW, Ryan MH, et al. Root microbiomes as indicators of seagrass health. FEMS Microbiol Ecol. 2019;96:fiz201.

Marzano M, Dandy N, Bayliss HR, Porth E, Potter C. Part of the solution? Stakeholder awareness, information and engagement in tree health issues. Biol Invasions. 2015;17:1961-77.

Marzano M, Woodcock P, Quine CP. Dealing with dieback: forest manager attitudes towards developing resistant ash trees in the United Kingdom. Forestry. 2019;92:554-67.

Massart S, Candresse T, Gil J, Lacomme C, Predajna L, Ravnikar M, Reynard J-S, et al. A framework for the evaluation of biosecurity, commercial, regulatory, and scientific impacts of plant viruses and viroids identified by NGS technologies. Front Microbiol. 2017;8:45.

McRoberts N, Hall C, Madden LV, Hughes G. Perceptions of disease risk: from social construction of subjective judgements to rational decision making. Phytopathology. 2011;101:654-65.

McRoberts N, Thomas CS, Brown JK, Nutter FW, Stack JP, Martyn RD. The evolution of a process for selecting and prioritizing plant diseases for recovery plans. Plant Dis. 2016:100:665-71.

McRoberts N, Figuera SG, Olkowski S, McGuire B, Luo W, Posny D, Gottwald T. Using models to provide rapid programme support for California's efforts to suppress Huanglongbing disease of citrus. Phil Trans R Soc B. 2019:374:20180281.

Meentemeyer RK, Dorning MA, Vogler JB, Schmidt D, Garbelotto M. Citizen science helps predict risk of emerging infectious disease. Front Ecol Environ. 2015;2015(13):189-94.

Mercado-Blanco J, Abrantes I, Barra Caracciolo A, Bevivino A, Ciancio A, Grenni $P$, et al. Belowground microbiota and the health of tree crops. Front Microbiol. 2018;9:1006.

Millar Cl, Stephenson NL. Temperate forest health in an era of emerging megadisturbance. Science. 2015;349:823-6.

Mills P, Dehnen-Schmutz K, Ilbery B, Jeger M, Jones G, Little R, MacLeod A, Parker S, Pautasso M, Pietravalle S, Maye D. Integrating natural and social science perspectives on plant disease risk, management and policy formulation. Phil Trans R Soc B. 2011;366:2035-44. 
Milne AE, Bell JR, Hutchison WD, van den Bosch F, Mitchell PD, Crowder D, Parnell S, Whitmore AP. The effect of farmers' decisions on pest control with Bt crops: a billion-dollar game of strategy. PLoS Comput Biol. 2015;11:e1004483.

Milne AE, Gottwald T, Parnell SR, Alonso Chavez V, van den Bosch F. What makes or breaks a campaign to stop an invading plant pathogen? PLoS Comput Biol. 2020;16:e1007570.

Mundy DC, Beresford RM. Susceptibility of grapes to Botrytis cinerea in relation to berry nitrogen and sugar concentration. NZ Plant Prot. 2007:60:123-7.

Nayak P, Mukherjee AK, Pandit P, Pradhan SK. Application of statistical tools for data analysis and interpretation in rice plant pathology. Rice Sci. 2018:25:1-18.

Newton AC, Fitt BDL, Atkins SD, Walters DR, Daniell T. Pathogenesis, mutualism and parasitism in the trophic space of microbe-plant interactions. Trends Microbiol. 2010a;18:365-73.

Newton AC, Gravouil C, Fountaine JM. Managing the ecology of foliar pathogens: ecological tolerance in crops. Ann Appl Biol. 2010b;2010(157):343-59.

Newton AC, Torrance L, Holden N, Toth I, Cooke DEL, Blok V, Gilroy EM. Climate change and defence against pathogens in plants. Adv Appl Microbiol. 2012;81:89-132.

Olmos A, Boonham N, Candresse T, Gentit P, Giovani B, Kutnjak D, Liefting L, et al. High throughput sequencing for plant pest diagnosis: challenges and opportunities. EPPO Bull. 2018;48:219-24.

Pautasso M. Responding to diseases caused by exotic tree pathogens. In: Gonthier P, Nicolotti G, editors. Infectious forest diseases. Wallingford: CABI; 2013. p. 592-612.

Pautasso M, Döring TF, Garbelotto M, et al. Impacts of climate change on plant diseases_opinions and trends. Eur J Plant Pathol. 2012;133:295-313.

Peiffer JA, Spor A, Koren O, Jin Z, Tringe SG, Dangl JL, et al. Diversity and heritability of the maize rhizosphere microbiome under field conditions. Proc Nat Acad Sci. 2013;110:6548-53.

Pinho D, Barroso C, Froufe H, Brown N, Vanguelova E, Egas C, Denman S. Linking tree health, rhizosphere physicochemical properties, and microbiome in acute oak decline. Forests. 2020;2020(11):1153.

Pitlik SD, Koren O. How holobionts get sick-toward a unifying scheme of disease. Microbiome. 2017;5:64.

Pixley KV, Falck-Zepeda JB, Giller KE, Glenna LL, Gould F, Mallory-Smith CA, Stelly DM, Stewart CN. Genome editing, gene drives, and synthetic biology: will they contribute to disease-resistant crops, and who will benefit? Annu Rev Phytopathol. 2019:57:165-88.

Rabiey M, Hailey LE, Roy SR, Grenz K, Al-Zadjali MAS, Barrett GA, et al. Endophytes vs tree pathogens and pests: can they be used as biological control agents to improve tree health? Eur J Plant Pathol. 2019;155:711-29.

Richard B, Jumel S, Rouault F, Tivoli B. Influence of plant stage and organ age on the receptivity of Pisum sativum to Mycosphaerella pinodes. Eur J Plant Pathol. 2012;132:367-79.

Salama NKG, Van den Bosch F, Edwards GR, Heard MS, Jeger MJ. 2012, Population dynamics of a non-cultivated biennial plant Tragopogon pratensis infected by the autoecious demicyclic rust fungus Puccinia hysterium. Fungal Ecol. 2012:5:530-42.

Sauter P, Hermann D, Mußhoff O. Risk attitudes of foresters, farmers and students: An experimental multimethod comparison. Georg-AugustUniversität Göttingen, Department für Agrarökonomie und Rurale Entwicklung (DARE), Göttingen. Diskussionsbeitrag No. 1514. 2015.

Savary S, Castilla NP, Elazagui FA, Teng PS. Multiple effects of two drivers of agricultural change, labour shortage and water scarcity, on rice pest profiles in tropical Asia. Field Crops Res. 2005;91:263-73.

Savary S, Mila A, Willocquet L, Esker PD, Carisse O, McRoberts N. Risk factors for crop health under global change and agricultural shifts: a framework of analyses using rice in tropical and subtropical Asia as a model. Phytopathology. 2011;101:696-709.

Savary S, McRoberts N, Esker PD, Willocquet L, Teng PS. Production situations as drivers of crop health: evidence and implications. Plant Pathol. 2017:66:867-76.

Savary S, Willocquet L, Pethybridge SJ, Esker P, McRoberts N, Nelson A. Assessing the global burden of pathogens and pests on major food crops. Nature Ecol Evol. 2019;3:430-9.
Scarlett K, Denman S, Clark DR, Forster J, Vanguelova E, Brown N, Whitby C. Relationships between nitrogen cycling, microbial community abundance and composition reveal the indirect effect of soil pH on oak decline. ISME J. 2020. https://doi.org/10.1038/s41396-020-00801-0.

Schneider SM, Rosskopf EN, Leesch JG, Chellemi DO, Bull CT, Mazzola M. United States Department of Agriculture-Agricultural Research Service research on alternatives to methyl bromide: pre-plant and post-harvest. Pest Manag Sci. 2003;59:814-26.

Schreiter S, Ding G-C, Heuer H, Neumann G, Sandmann M, Grosch R, et al. Effect of the soil type on the microbiome in the rhizosphere of fieldgrown lettuce. Front Microbiol. 2014;5:144

Seidl R, Honkaniemi J, Aakala T, Aleinikov A, Angelstam P, Bouchard M, et al. Globally consistent climate sensitivity of natural disturbances across boreal and temperate forest ecosystems. Ecography. 2020;43:967-78.

Sessitsch A, Pfaffenbichler N, Mitter B. Microbiome applications from lab to field: facing complexity. Trends Plant Sci. 2019;24:194-8.

Showalter DN, Saville RJ, Orton ES, Buggs RJA, Bonello P, Brown JKM. Resistance of European ash (Fraxinus excelsior) saplings to larval feeding by the emerald ash borer (Agrilus planipennis ). Plants People Planet. 2020:2:41-6.

Stevenson KL, McGrath MT, Wyenandt CA. Fungicide resistance in North America. 2nd ed. Saint Paul: APS Press; 2019.

Stocks JJ, Buggs RJA, Lee SJ. A first assessment of Fraxinus excelsior (common ash) susceptibility to Hymenoscyphus fraxineus (ash dieback) throughout the British Isles. Sci Rep. 2017;7:16546.

Stovall AEL, Shugart HH, Yang X. Reply to "height-related changes in forest composition explain increasing tree mortality with height during an extreme drought." Nat Comm. 2020;11:3401.

Sumner DA. Exotic pests and diseases: biology and economics for biosecurity. Ames: lowa State Press; 2003. p. 245.

Tamm LC, Holb I. Direct control of airborne diseases. In: Finckh MR, van Bruggen AHC, Tamm L, editors. Plant diseases and their management in organic agriculture. St Paul: APS Press; 2015. p. 205-16.

Tessmann DJ, Dianese JC, Miranda AC, Castro LHR. Epidemiology of a neotropical rust (Puccinia psidii): periodical analysis of the temporal progress in a perennial host (Syzygium jambos). Plant Pathol. 2001;50:725-31.

Tilston EEL, Deakin G, Bennett J, Passey T, Harrison N, O'Brien F, et al. Candidate causal organisms for apple replant disease in the UK. Phytobiomes J. 2018;2:261-74.

Tkacz A, Hortala M, Poole PS. Absolute quantitation of microbiota abundance in environmental samples. Microbiome. 2018;6:110.

Tsolakidou M-D, Stringlis IA, Fanega-Sleziak N, Papageorgiou S, Tsalakou A, Pantelides IS. Rhizosphere-enriched microbes as a pool to design synthetic communities for reproducible beneficial outputs. FEMS Microbiol Ecol. 2019;95:fiz138.

Van den Bosch F, Oliver R, van den Berg F, Paveley N. Governing principles can guide fungicide resistance management tactics. Annu Rev Phytopathol. 2014;52:155-74.

VanDersal JM. Managing plant diseases offshore. Australasian Plant Pathol. 2007;36:520-3.

Villamor DEV, Ho T, Al Rwahnih M, Martin RR, Tzanetakis IE. High throughput sequencing for plant virus detection and discovery. Phytopathology. 2019;109:716-25.

Vonaesch P, Anderson M, Sansonetti PJ. Pathogens, microbiome and the host: emergence of the ecological Koch's postulates. FEMS Microbiol Rev. 2018;42:273-92.

Walters D, Lyon GD, Newton AC. Induced resistance for plant defence: a sustainable approach to crop protection. In: Walters D, Lyon GD, Newton AC, editors. Induced resistance for plant defence: a sustainable approach to crop protection. 2nd ed. Oxford: Blackwell Science; 2014. p. 2014.

Wang Y, Zhang W, Ding C, Zhang B, Huang Q, Huang R, Su X. Endophytic communities of transgenic poplar were determined by the environment and niche rather than by transgenic events. Front Microbiol. 2019;10:588.

Weber RWS. Resistance of Botrytis cinerea to multiple fungicides in northern German small fruit production. Plant Dis. 2011;95:1263-9.

Xu X-M, Robinson JD. Effects of fruit maturity and wetness on the infection of apple fruit by Neonectria galligena. Plant Pathol. 2010;59:542-7. 
Yassin M, Ton J, Rolfe SA, Valentine T, Cromey M, Holden N, Newton AC. The rise, fall, and resurrection of chemical induced resistance agents. Pest Manag Sci. 2021. https://doi.org/10.1002/1526-4998.

Yuen JE, Hughes G. Bayesian analysis of plant disease prediction. Plant Pathol. 2002;57:407-12.

Zarco-Tejada PJ, Camino C, Beck PSA, Calderon R, Hornero A, Hernández-Clemente $\mathrm{R}$, et al. Previsual symptoms of Xylella fastidiosa infection revealed in spectral plant-trait alterations. Nat Plants. 2018;4:432-9.

Zhang Y, Li S, Li H, Wang R, Zhang K-Q, Xu J. Fungi-nematode interactions: diversity, ecology, and biocontrol prospects in agriculture. J Fungi. 2020;6:206
Zicca S, De Bellis P, Masiello M, Saponari M, Saldarelli P, Boscia D, Sisto A. Antagonistic activity of olive endophytic bacteria and of Bacillus spp. strains against Xylella fastidiosa. Microbiol Res. 2020;236:126467.

\section{Publisher's Note}

Springer Nature remains neutral with regard to jurisdictional claims in published maps and institutional affiliations.
Ready to submit your research? Choose BMC and benefit from:

- fast, convenient online submission

- thorough peer review by experienced researchers in your field

- rapid publication on acceptance

- support for research data, including large and complex data types

- gold Open Access which fosters wider collaboration and increased citations

- maximum visibility for your research: over $100 \mathrm{M}$ website views per year

At BMC, research is always in progress.

Learn more biomedcentral.com/submissions 